\title{
A STUDY OF ISSUES AND CHALLENGES OF RETAIL BANKING
}

\author{
Prof. Yogita Kadam (Assistant Professor) \\ Prof.Aruna Kulkarni, \\ Ms.Daksha Porwal \\ TIMR, Pune
}

\begin{abstract}
:
Generally, a financial institution caters to buyers of more than a few stature inclusive of company clients, institutional clients, authorities and the everyday small banking patron who solely appears for an account for his earnings profits or financial savings and this is the goal target market of retail banking section of any financial institution which affords merchandise appropriate for the want of such clients. The retail consumers have decrease transaction fee and want money owed for income, financial savings account, time period deposits loans, and so on.

The purpose of this paper is to study recent trends and issue and the challenges in retail banking. The secondary data is used for this study. The analysis showed banks are facing challenges in the era of digitization and heavy competition. Banks need to get ahead of these challenges and retool to win in competitive market. They want to learn to be agile, progressive and adaptable in an effort to execute efficiently and deal with uncertainty because the future unfolds. They need to do things in another way.
\end{abstract}

Keywords: Retail Banking, stakeholders, challenges of retail banking.

\section{Introduction:}

In the recent past years Retail banking has emerge as important drivers of overall banking industry in India. The functions of Retail banking include loans, credits, depository services, credit cards, money management and other financial services for individuals and families.

Retail banking involve serving of products on both asset and liability facet of the balance sheet eg. fixed, present day / financial savings debts on the legal responsibility facet; and mortgages, loan(e.g., nonpublic,housing, car, and educational) on the asset aspect.

The retail banking services generally correspond to the banking offerings presenting inside the intermediary degree of development of banking. even as retail banking offers exceptional possibilities for growth, the demanding situations are equally daunting. The exacting regulatory necessities on the consumer safety the front, risks from a slowing worldwide economic system and growing customer expectancies suggest that banks ought to innovate to grow. This paper tries to observe the issues and challenges of retail banking 


\section{Characteristics of Retail Banking:}

The retail banking is characterized by multiple products, multiple delivery channels and multiple customer segments. The multiple products may include financial products such as deposits, insurance products (agency), investments etc.

The multiple delivery channels may include customer service centers, internet kiosks etc.

Multiple customer segments may include the individual customers, small businessmen and corporate.Bank directly execute the transactions with customer

\section{Drivers for Development of Retail Banking:}

- converting client Demographics

- growing disposable earning

- Youngest population in the international

- increasing literacy levels

- higher adaptability to technology

- growing consumerism

- monetary incentives for home loans

- changing mindsets-willingness to borrow/lend

- choice to improve life

- Banks vying for better market share

\section{Significance of the study-}

Retail banking consists of a completely big and complete range of economic merchandise like, residential mortgage, loans for consumer durables, automobile finance, deposit products, loans against equity stocks, credit score cards, debit playing cards, non-public loans, loans for preliminary Public offer (IPO) and so on.

As the technology and world is growing so fast, the banking sector also needs to undergo some of the significant changes in order to meet the ever increasing requirements of the customers and the world. To make this process hassle-free and to understand the challenges faced by the banks to gather the customer requirement and undergo these changes, this study is being conducted to understand the potholes in the ongoing process and just to rectify it in all the possible ways. Offerings provided by means of retail banks encompass checking and savings debts, mortgages, private loans, credit cards, and certificates of deposit .Retail banking is the part and parcel of everyone's life and it provides a variety of services to everyone in all possible ways. Just to improve their functionality and provide customer satisfaction, this study is essential. 


\section{Objectives of the study:}

1. To examine the latest trends in retail banking.

2. To study the difficulty and the demanding situations in retail banking three.

3. To ensure a excessive delight stage and reduce the proportion of complaints of clients in retail banking.

\section{Literature Review:}

The literature related to retail banking has been reviewed on this studies.

Essam E Ibrahim et al., (2006) explored the important thing elements of the digital carrier nice (ESQ) perceptions of united kingdom banking customers and evaluated the customers' perceptions of their banks' real overall performance on the identified ESQ dimensions in their observe. The six composite dimensions of electronic service high-quality are exposed. Analysis using importance performance analysis found out that the United Kingdom clients' perceptions in their bank real performance on those found out that ESQ dimensions were in large part modest.

Istvan Szuts (2008), in his paper titled as "consumer Loyalty issues in Retail Banking" highlighted that to obtain better enterprise growth, banks must growth client loyalty by using delivering a extraordinary revel in that combines the right blend of convenience, value and service and forge an emotional bond with clients.

Phanindra Kumar and B. Parashuramulu (2013) concluded that whilst retail banking offers out of the ordinary opportunities for growth, the demanding situations are equally daunting. How some distance the retail banking is capable of lead increase of the banking industry in destiny could depend on the capacity building of the banks to fulfill the demanding situations and employ the opportunities profitably.

Arun Kumar, et al., (2010) examined the service high-quality dimensions of Indian personal banks handling retail banking. The results discovered that responsiveness and reliability of service nice dimensions decide consumer satisfaction extra than assurance, empathy and tangible aspects. They concluded that the overall perceived provider exceptional results in consumer's attitudinal loyalty thru customer satisfaction.

Imamul Haque, S.M. (2013), ” exposed that the provider nice measurement of 'tangibility' measures the physical capabilities, bodily look, physical cloth along with pamphlets and so on. and reception desk employees in his paper titled "Retail Banking in India on account that 1991: A 
Comparative study of Public quarter Banks and personal area Banks

The perception of customers regarding the dimension tangibility'among public area banks and personal zone banks is distinctive. The customers of private region banks

have advantageous mindset closer to the bodily centers of their banks in evaluation to the clients of public area banks. The suggest values of personal quarter banks is higher in contrast to public quarter banks which identifies that there's enormous variation in the notion of customers concerning the carrier great measurement of reliability between public and personal quarter banks.

\section{Research Methodology:}

To study this particular topic descriptive method of research has been adopted. The data was collected from the secondary sources such as magazines, preserved information in the banks database, bank websites, journals, etc.

\section{Results and Discussions:}

With the help of secondary data following results has been ascertained which states about Retail banking issues and challenges:

\section{The Current Scenario In Retail Banking :}

The recent wave of innovation in technology, across all fields, has left retail banks with only two options one is traditional banking and other is work as per demand of the changing time period. The customers are choosy they want quick results and retail banks need to work as per customers expectations all the times. The features of retail banking includes direct banking, smart devices, biometrics, banking for all.

Every retail bank has its own method and strategy to overcome the obstacles. The success of bank depends upon the six factors

- Customer centric business strategies development

- Simple business \& operating models

- Optimizing distribution

- Collecting and Obtaining information advantage

- Effective management of capital, risk, and regulations proactively

- Enable innovation

\section{II. demanding situations Of Retail Banking:}

- No Social Media for Retail Banks:

best two- 0.33 of retail banks across the world\& one- $1 / 3$ across the India don't have any 
plans in region to use social media in any manner. Social media consists of facebook, Twitter and related in amongst other networking web sites.

- Retail Lending Scheme:

In industry hobby financial institution have aggressively increased the share of credit toward the retail lending The important assignment for the banking industry is approachability and accessibility, the ability to make finance available to folks who need it, once they desired. The industry need to grow to be proactive and attain the customer as opposed to watching for the customer to attain out to the company/enterprise.

\section{- Outsourcing:}

The Indian banks are outsourcing the hardware software program upkeep, TM installation which effects in difficulty of Outsourcing .

- Maintaining client Loyalty:

customer service should be on the quit all in retail banking. The approach of knowing Your customer (KYC) is important because it takes days/months to find a excellent customer however handiest seconds /mins

to lose one. to meet and fulfill clients wishes and demand banks are required to undertake revolutionary strategies. The patron retention is of paramount vital for the profitability if retail banking business, to growth the marketplace share , banks need to retain their purchaser.

- Fraud Prevention:

The dependency on era has delivered IT departments' extra responsibilities and challenges in managing, keeping and optimizing the performance of retail banking networks. The renovation of enhance degree safety is very essential for religion and agree with of customers. Regulatory compliance based on fatherland safety, IT framework and privateness rules are forcing financial institutions to combine the databases and overhaul the statistics structures.

\section{- Different challenges faced by way of banks consists of :}

- Designing their very own economic product may be very high priced.

- excessive desire in internet banking it hard to the banks because of sluggish in Introducing technology based merchandise, finding it hard to keep the patron.

- patron are getting attracted toward different financial products like byproduct marketplace, mutual fund etc.

- increasing opposition, employee productivity, the strain to preserve up with the change in present day marketplace state of affairs, clients preferences and alternatives, general cost management, short consequences call for, and overall of customer expectancies.

- some of the important thing coverage problems relevant to the retail banking sector are: economic inclusion, accountable lending, get admission to to 
finance, long-term savings, monetary functionality, purchaser safety, law and monetary crime prevention.

\section{Strife In Retail Banking:}

The entry of new generation personal quarter banks has changed the whole scenario. earlier the household financial savings went into banks and the banks lent out money to company. Now they need to promote banking. The retail section, which become earlier unnoticed, is now the most important of the lot, with the banks jumping over one some other to give out loans. The purchaser has never been so fortunate with so many banks providing so many products to pick from. With deliver a long way exceeding call for it has been a race to the bottom, with the banks undercutting one some other. loads of overseas banks have already burnt their hands in the retail game and feature now decided to get out of some retail segments completely. The nimble footed new generation personal quarter banks have taken a lead in this front and the public region banks (PSBs) are trying to play catch up. The PSBs have been losing business to the personal area banks in this phase. PSBs want to determine out the way to generate profitable business inside the days to return.

\section{Finding and Suggestions:}

1. To enlist the "unbanked" section of the society by using the carrier vendors is a technique to amplify the retail market. it's far this underserved section should end up the point of interest for the banks.

2. Rural credit or Agricultural credit is a phase to be explored. it could be taken into consideration as an unbanked phase. It has continually been seemed upon as a charitable interest in preference to a profitable hobby.

3.Now, the time has come for the patron to call for a product that is not currently to be had in the Bankers kitty and the bank has to actually create purchaser-precise products. Banker is expected to assume the role of a financial Engineer.

4. Banks should decrease the minimum deposit requirement for starting new money owed as announced by using RBI. To obtain greater economic inclusion, all banks need to make available a basic banking ,no frills" account either with ,nilee or very low minimal balances as well as charges that might make such bills handy to full-size sections of population.

5. Banks should permit the sooner centers to sink into the tradition of the clients earlier than any new facilities are released. also, the earlier facilities ought to be embedded with services in order that customers now not best recognize new era, however also are in a function to perform.

6 . For the efficient management of a big and various retail portfolio, the most crucial pre-considered necessary is the professional and well-versed employees.

handiest skilled man strength can resist the rigour of administering a diverse and complicated retail credit portfolio.

7. The blessings following out of go-promoting and up-promoting will remain a miles cry within the absence of sturdy information warehouse wherein from meaningful statistics about clients, their choices, their spending patterns, and many others, can be mined. data warehouse is crucial for fulfillment in retail banking. 
8. A full fledged advertising and marketing department/division could help in evolving a emblem strategy, deal with the problem of alienation from the upwardly cellular, high internet really worth patron organization and improve the remember value of the organization and its merchandise by way of arresting the fashion of getting receded from public reminiscence.

9.It's time to break the parable that public quarter banks aren't patron friendly. Banks need to observe patron pleasant approach to beautify the marketing in their retail banking products. Banks should supply the products and offerings swiftly in a dynamic market.

10. Broaden the agricultural retail banking by using manner of neighborhood area banks (LABs), Selfhelp groups (SHGs) with bank linkages became any other indigenously developed banking version. partnership model, the MFI evaluates, recommends, originates the loans, enables in disbursal and eventually tracks and collects the loans the Kisan credit score Card (KCC)that allows the farmer to get loans over a three to 5years period as a revolving credit entitlement, for this reason, presenting them control over their coins flows and decreased transaction costs for both the banks and the farmers. 11. Retail banks in the direction of social media is a primary issue in an era of aggressive competition. The banks with out a social media approach are being short sighted and are putting themselves in a risky and vulnerable position as compared to competition who've realised that social media can and must play an intrinsic function in their commercial enterprise.

12. The technological base and efficiency in operations might deliver the retail banking market a competitive part and could make contributions in the achievement of the commercial enterprise in India. top importance has to take delivery of to client interest.

13. The purchaser database available with the banks is the high-quality supply of their demographic and monetary statistics and can be used by the banks for concentrated

on certain customer segments for brand new or modified product. The banks ought to come out with new merchandise inside the location of securities, mutual budget and insurance.

14. The branch machine is widely considered as the important thing element of attracting and serving clients who call for advice, even as direct channels are increasingly used to execute transactions. achieving a unbroken interface amongst channels is a task for plenty big and complicated banks. Upgrading department workforce to provide recommendation and 'client experience' is also a concern.

15. destiny retail strategies will recognition on deposit-accumulating, go-selling to present customers in preference to new customer acquisition, and growing systems which enable management to tune customer wishes and relative profitability. 16. within the geographic measurement, as a result of the crisis many retail banks are withdrawing to their center markets in which they have got a large market percentage.

then again, leading banks in dynamic emerging markets including India and Brazil are located to amplify in their area

\section{Conclusion:-}

Banks need to get in advance of these challenges and retool to win in 2020.They want to learn to be agile, modern and adaptable with the intention to execute correctly and address uncertainty as the future unfolds. They want to do matters in another way. And one that takes an quit-to-cease view integrating the modifications in markets, customers, hazard, law, operations, technology - and the demanding situations of imposing actual-international massive-scale alternate.. Globalization, 
consolidation and want of understanding are notably redefining the banking taxonomy. accordingly, the participants, be it a Indian financial player or a overseas entrant within the retail region should undertake a special method in everything viz., products, offerings to preserve the Indian marketplace proportion, as a popular pronouncing goes as variety is the spice of existence. The actual challenge for the banks inside the modern-day state of affairs is to face out inside the midst of hard-hitting regulations of the apex body. Globalization, consolidation and want of knowledge are notably redefining the banking taxonomy. as a result the individuals, be it a Indian economic participant or a overseas entrant within the retail zone have to adopt a exclusive approach in the entirety viz., merchandise, services to maintain the Indian market share, as a famous pronouncing goes as variety is the spice of life. destiny.

Future Scope of Study:

1. Different Approaches of Retail banking in India.

2. Digitalization and Retail banking.

\section{REFERENCES}

\section{Books:-}

- Indian Banking: Natrajan.

- Bank Management by- Vasant Desai

- Hajela T.N. (2009) "Banking Reforms” Anne Books Pvt. Ltd., New Delhi

\section{Web Sites:-}

- wWw.rbi.gov.in

- www.economictimes.com

- www.jjsbl.com

- https://www.pwc.com

\section{Journals:}

Jaiswal, K.S. \& Nettu Singh "Retail Banking: Indian Scenario", Indian Journal of Marketing, New Delhi, Vol. XXXVII No.10, Jan, 2008.

Rajni Sofat \& Preeti Hiro "Creativity and Innovations in Retail Banking", Indian Journal of Marketing, New Delhi, Vol. XVI No.10, Sep, 2007

Saurabh Goyal "Retail Banking: An Essence of Present Banking System" Journal of Banking \& Finance, Kolkata, Vol - XII, No. 1, Nov, 2007.

Swami. B.K. (2008) "Commercial Banking in the Changing Scenario”, Excel Books, New Delhi 
Essam, E Ibrahim, Matthew Joseph and Kevin Ibeh, (2006), -Customers' Perception of Electronic Service Delivery in the UK Retail Banking Sectorll, International Journal of Bank Marketing, Vol.24(7), Pp.475-493.

Istvan Szuts (2008), - Loyalty Problems in Retail Banking\|, 6th International Conference on Management, Enterprise and Bench Marketing, Budapest, Hungry.

Arun Kumar, S. Tamil Mani, B. Mahalingam, S. and Vanjikovan, M. (2010), -Influence of service Quality on Attitudinal Loyalty in Private Retail Banking: An Empirical Studyll, The IUP Journal of Management Research, Vol. 9(4), Pp.21-38

Imamuel Haque, S.M. (2013), —Retail Banking in India Since 1991: A Comparative Study of Public Sector Banks and Private Sector Banksl, Aligarh University, Aligarh, India.

K. Phanindra Kumar \& B. Parashuramulu, “ Indian Retail Banking Industry: Opportunities \& Challenges “Asian Journal Of Multidimensional Research Vol.2 Issue 5, May 2013, ISSN 2278-4853. 